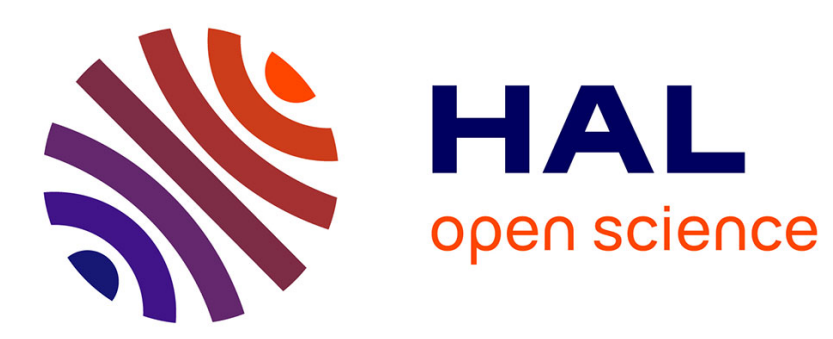

\title{
Noise reduction of a double-skin façade considering opening for natural ventilation
}

Jean-Philippe Migneron, André Potvin

\section{To cite this version:}

Jean-Philippe Migneron, André Potvin. Noise reduction of a double-skin façade considering opening for natural ventilation. Acoustics 2012, Apr 2012, Nantes, France. hal-00810636

\section{HAL Id: hal-00810636 \\ https://hal.science/hal-00810636}

Submitted on 23 Apr 2012

HAL is a multi-disciplinary open access archive for the deposit and dissemination of scientific research documents, whether they are published or not. The documents may come from teaching and research institutions in France or abroad, or from public or private research centers.
L'archive ouverte pluridisciplinaire HAL, est destinée au dépôt et à la diffusion de documents scientifiques de niveau recherche, publiés ou non, émanant des établissements d'enseignement et de recherche français ou étrangers, des laboratoires publics ou privés. 


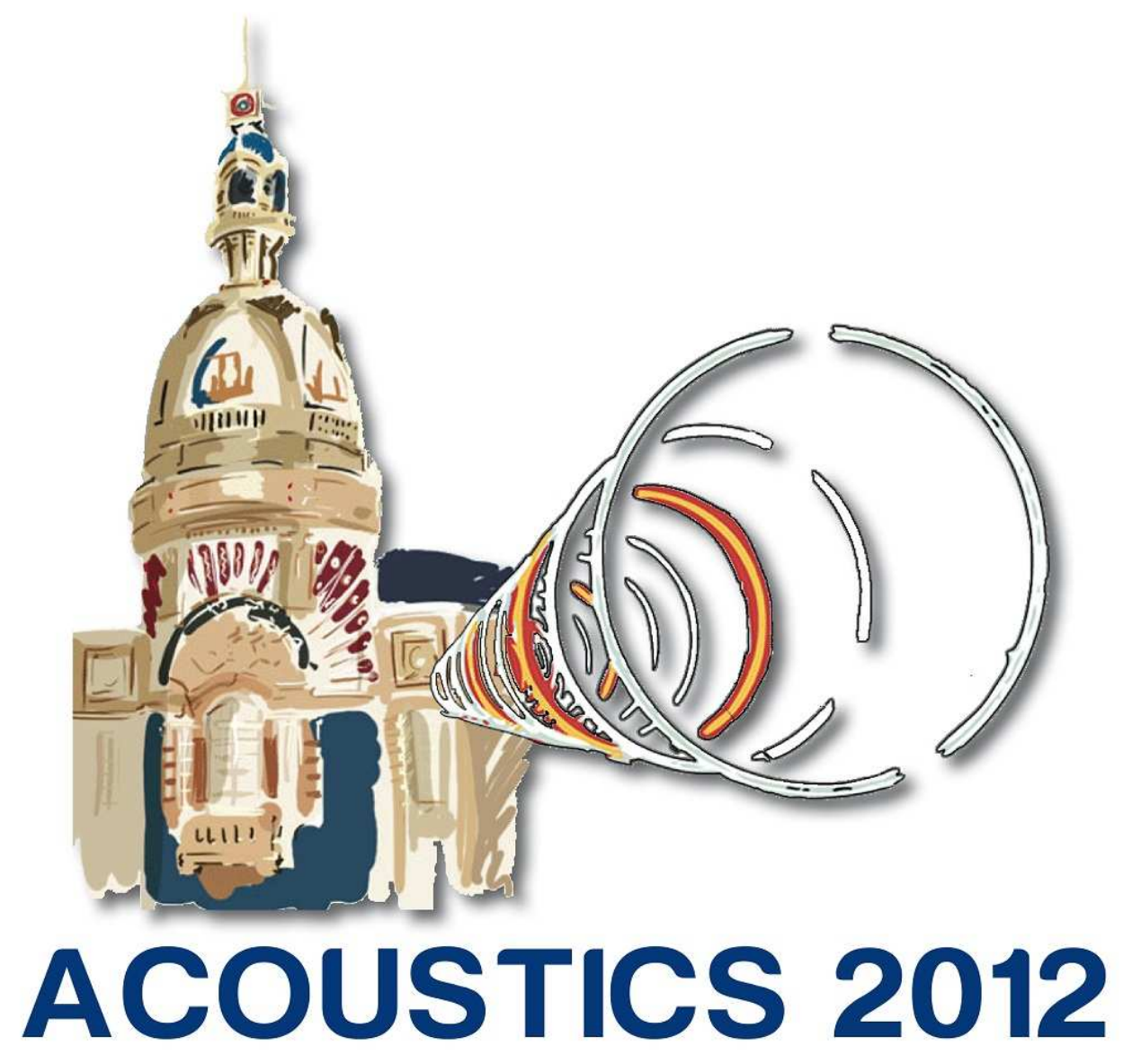

Noise reduction of a double-skin façade considering opening for natural ventilation

J.-P. Migneron and A. Potvin

Université Laval,

jean-philippe.migneron.1@ulaval.ca 